\section{GENERAL CIRCULATION MODEL OF CLIMATE CHANGE IN THE LOWER RIVER NIGER} NIGERIA

\section{Onafeso, Olumide David}

Department of Geography, Olabisi Onabanjo University, Ago-Iwoye, Nigeria olumide.onafeso@oouagoiwoye.edu.ng

\section{ABSTRACT}

Climate change has serious implications for water resources management and river flow based socioNigeria. This study employed Runs test to examine annual deviations in rainfall which suggest shred of evidence of climatic change. Temporal trends were estimated using time series analysis employing auto regressive moving average (ARIMA) model. Rainfall outputs of three General Circulation Models (CGCM3, CSIROMk3 and HadCM3) were compared with conventional rain-gauge amounts using T-test analysis. Higher resolutions of GCM rainfall predictions from the HadCM3 model were derived from statistical downscaling model combining stepwise regression and Bayesian forecas assimilation techniques. Rainfall-runoff relationships were examined with linear regression considering runoff $(\mathrm{y})$ and down scaled HadCM3 rainfall predictions A1, A2 and B1 SRES emissio scenarios of the lower River $\operatorname{Niger}(\mathrm{X})$. Results revealed a significant trend in rainfall variabilities showing shreds of evidence of climate change. Downscaled rainfall had minimum bias from the difference at 0.05 -level of significance. Future runoff predictions revealed $2 \%$ to $40 \%$ increase for dry season runoff from 1961-1990 mean levels, $45 \%$ reduction for wet season in the upper reaches with $17 \%$ to $60 \%$ increase in the middle to lower reaches. In conclusion, future runoff predicted from statistically downscaled HadCM3 rainfall model suggest high variability and as such adaptation to drought and flood in the north and south respectively are recommended.

Keywords: Rainfall, Runoff, General Circulation Model, HadCM3, Nigeria

Accepted Date: 23 May, 202

\section{INTRODUCTION}

Recent breakthroughs in spatial coverage and temporal resolutions of climate conditions have made it possible to validate climate models, thus improving their reliability for future predictions (McGuffie and Henderson-Sellers, 2001). According to the IPCC 2007 Assessment Report, the number of Regional Climate Model investigations over Western Africa is limited compared to other regions. This may as well be the reason why the climate of the region is not well understood (Narimisa and Narimisa, 2018; Christensen et al., 2007). The life-blood of the economies of West African countries is insufficient water resources (Akintola, 1978). Over $70 \%$ of the inhabitants depend primarily on rain-fed agriculture for their livelihood. Moreover, hydropower is the main source of electric power

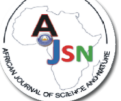

P-ISSN 2536-6904, E-ISSN 2705-2761 generation which is crucial for socio-economic development and is strongly dependent on the availability of rainfall. Changes in the amounts an distribution of rainfall would, have significan impacts on water availability and thereby directly (Kunstmann and Jung, 2005). Climate change is probably one of the most challenging pressures facing hydrological systems and water presoures. This is because temperature an precipitation can have a direct impact on changes in surface runoff, evapotranspiration, groundwate levels, reserves and quality. Previous studies have focused on the hydrological impacts of climate change on whole countries and river basins using scenarios, for example, Lebanon (Hreiche et al. 2005); Benin (Bormann et al., 2005); the Nordic region (Beldring, 2007); and the USA (Leung and influence socio-economic activities in the region
Qian, 2005). Although the potential impacts of climate change on water resources of the Nigerian sector of the Niger River basin of sub-Saharan West Africa has been assessed with simulation models, Thornthwaite water balance accounting scheme and artificial neural network ANN (Okpara and Perumal, 2009), the study only employed hypothetical climate change scenarios which are less predictive of future climates suitable for reliable hydrological impact assessments. Leung and Qian (2005) examined the control (1975-1995) and future (1995-2100) climate simulated by a global climate model GCM and regional climate simulation driven by the GCM control simulation for the USA. High-resolution outputs of General
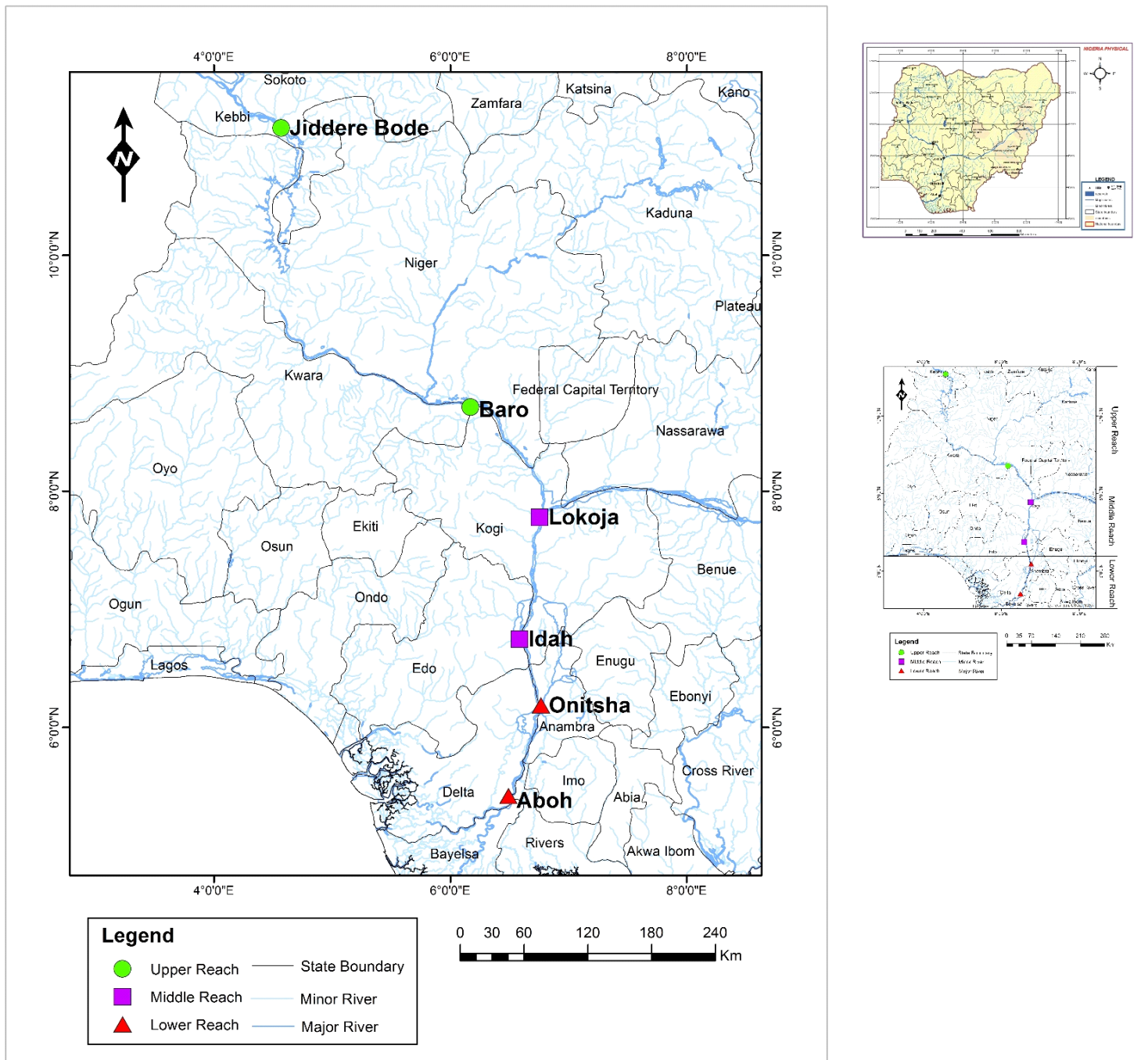

Fig. 1 Map of Nigeria indicating the study are
Circulation Models suitable for climate change impact assessments at a local scale can be derive from statistical downscaling thus, making informed water resources management possible. The Lower River Niger (LRN) as shown in Fig. 1, is a major source of water for Nigeria (Kunstmann and Jung, 2005). A shift in climate trend would alter the flows of this river thereby affecting hydroelectricity generation, irrigation agriculture, ansportation and other water-related socio-economic activities along the floodplains. This study models future rainfall and runoff to improve our understanding of this resource to evolve measures in meeting climate change challenges. 


\section{Materials and Methods}

River Niger is the major drainage lengthening about $4,180 \mathrm{~km}$ with a total basin area of 2,117,700 $\mathrm{km}^{2}$ acros West Africa from southeastern Guinea highlands through Mali and Niger on the border with Benin to it mouth where it discharges into the Atlantic Ocean in the Niger Delta of Nigeria. The Lower River Nige (LRN) which is the focus of this study starts with the entry point into Nigeria with its first gauge at Jiddere Bode in Kebbi State. Data was collected from six (6) gauging stations downstream including Jiddere Bode and Baro representing the upper reach of the LRN, Lokoja and Idah representing the middle reach, as well as Onitsha and Aboh representing the lower reach of the stretch of study. Temporal trends in the annual rainfall model. The time series consist of elements that are serially dependent in the sense that one can estimate coefficient or a set of coefficients that describe consecutive elements of the series from specific, time-lagged (previous) elements. This can be summarized in the equation:

$x t=\xi+\Phi_{1} * x(t-1)+\Phi_{2} * x(t-2)+\Phi_{3} * x(t-3)+\ldots+\varepsilon$

(1)

where, $\xi$ is a constant that is the intercept, and $\Phi_{1}, \Phi_{2}, \Phi_{3}$ are the autoregressive model parameters. In other words, each observation is made up of a random error component or a random shock $\varepsilon$ and a linea combination of prior observations. Furthermore, independent from the autoregressive process, each element in the series can also be affected by the past error (or random shock) that cannot be accounted for by the autoregressive component, that is:

$x t=\mu+\varepsilon_{t}-\theta_{1} * \varepsilon_{(t-1)}-\theta_{2} * \varepsilon_{(t-2)}-\theta_{3} * \varepsilon_{(t-3)}-\ldots$

where $\mu$ is a constant, and $\theta_{1}, \theta_{2}, \theta_{3}$ are the moving average model parameters.

Raw rainfall outputs of three General Circulation Models (CGCM3, CSIROMk3 and HadCM3) for 1961990 were each compared with conventional rain-gauge measured corresponding rainfall amounts using Ttest analysis. The t-test,which is the most commonly used method to evaluate the differences in mean between two groups, is also employed to further test the time series model. The significance p-level is also computed with the t-test representing the probability of error involved in accepting the research hypothesis about the existence of a difference. Since the resolution of the GCMs is considerably too low for local climate change assessments on a point pattern basis, the need for downscaling the GCM comes to the fore.

However, the three different GCMs obtained for this study were run based on entirely different grid systems and resolutions; the question of the grid also becomes pertinent. The resizing of the study area thus makes it easier for the utilization of GCM predictions in this study at all. While Table 1 presents the grid point nearest each of the gauging stations adopted in this study, Table 2 presents the resizing of the study area visa-vis the grid systems of the GCMs employed.

\section{Table 1 GCM grid points nearest each of the gauging stations}

\begin{tabular}{lllllllll} 
& \multicolumn{1}{l}{ Actual location } & \multicolumn{2}{l}{ CGCM3 } & \multicolumn{2}{l}{ CSIROMk3 } & \multicolumn{2}{l}{ HadCM3 } \\
& \multicolumn{1}{l}{ Long. } & Lat. & Long. & Lat. & Long. & Lat. & Long. & Lat. \\
\cline { 2 - 9 } & $4^{\circ} 07^{\prime} \mathrm{E}$ & $11^{\circ} 23^{\prime} \mathrm{N}$ & 3.75 & 9.277853 & 3.75 & 10.2589 & 3.75 & 10 \\
Jiddere Bode & $6^{\circ} 23^{\prime} \mathrm{E}$ & $8^{\circ} 35^{\prime} \mathrm{N}$ & 7.5 & 9.277853 & 7.5 & 8.39367 & 7.5 & 10 \\
Baro & $6^{\circ} 44^{\prime} \mathrm{E}$ & $7^{\circ} 49^{\prime} \mathrm{N}$ & 7.5 & 9.277853 & 5.625 & 6.52841 & 7.5 & 7.5 \\
Lokoja & $6^{\circ} 43^{\prime} \mathrm{E}$ & $7^{\circ} 06^{\prime} \mathrm{N}$ & 7.5 & 9.277853 & 5.625 & 6.52841 & 7.5 & 7.5 \\
Idah & $6^{\circ} 45^{\prime} \mathrm{E}$ & $6^{\circ} 10^{\prime} \mathrm{N}$ & 7.5 & 5.566714 & 7.5 & 6.52841 & 7.5 & 5 \\
Onitsha & $6^{\circ} 31^{\prime} \mathrm{E}$ & $5^{\circ} 32^{\prime} \mathrm{N}$ & 7.5 & 5.566714 & 5.625 & 6.52841 & 7.5 & 5 \\
Aboh & & & & & & & & \\
\hline
\end{tabular}

\section{Table 2 Locational extent of the resized study units}

\begin{tabular}{lllllllll}
\hline & Longitudinal & Latitudinal & CGCM3 & \multicolumn{2}{l}{ CSIROMk3 } & \multicolumn{2}{c}{ HadCM3 } \\
& Extent & Extent & Long. & Lat. & Long. & Lat. & Long. & Lat. \\
\hline UPPER REACH & $3^{\circ}-7^{\circ} \mathrm{E}$ & $8^{\circ}-12^{\circ} \mathrm{N}$ & 3.75 & 9.277853 & 3.75 & 10.2589 & 3.75 & 10 \\
MIDDLE REACH & $6^{\circ}-7^{\circ} \mathrm{E}$ & $7^{\circ}-8^{\circ} \mathrm{N}$ & 7.5 & 9.277853 & 5.625 & 6.52841 & 7.5 & 7.5 \\
LOWER REACH & $6^{\circ}-7^{\circ} \mathrm{E}$ & $5^{\circ}-7^{\circ} \mathrm{N}$ & 7.5 & 5.566714 & 7.5 & 6.52841 & 7.5 & 5
\end{tabular}

Higher resolutions of GCM rainfall predictions from HadCM3 model were derived through a statistical downscaling model using a combination of stepwise regression and Bayesian forecast assimilation techniques. The Bayesian method which is normally used for updating prior information when new information becomes available is further employed to deduce a new series from the coefficients of the prediction equation derived from the stepwise regression. While the prior information about the rainfall which is the HadCM3 predictions for the present day (1961-1990) climate is considered as $y$, the series is represented mathematically by the probability density function $p(y)$. The variance of $p(y)$ is considered as the initial knowledge of $p(y)$ while the regression coefficients of the predictor variables' influence on $\mathrm{HadCM} 3$ predictions of rainfall $y$ as derived from the NCEP reanalysis is considered the additional new forecast information $x_{1}, x_{2} \ldots x_{n}$. The probability density function of the initial HadCM3 prediction $\mathrm{p}(\mathrm{y})$ is then updated to obtain the posterior conditional probability density function $p(y \mid x)$ by making use of the Baye's theorem of the form:

$$
\underline{p(y) p\left(x_{1} \ldots x_{n} \mid y\right)}
$$$$
p(y \mid x)=p\left(x_{1} \ldots x_{n}\right)
$$

The likelihood $p\left(x_{1} \ldots x_{n} \mid y\right)$ is an essential ingredient in the Bayesian procedure. The forecast assimilation $p(y \mid x)$ is therefore considered as the downscaled $\mathrm{HadCM} 3$ predictions which are further employed in the study. Rainfall-ruther Rainfall-runoff relationships were examined by employing the linear regression considering runoff as $Y$ (dependent variable) and the downscaled HadCM3 rainfall predictions under the A1, A2 and B1 SRES emission scenarios in each of the reaches of the lower River Niger as $X$ (independent variable).

\section{Result and Discussion}

Rainfall amounts vary significantly over long time scales; while the amount of water in the atmosphere is gained by evaporation, it is lost from the atmosphere through precipitation after complex intervening processes of both horizontal and vertical transport and changes in the physical state of water itself. Although the dependability of rainfall from year to year, the characteristic of seasonal distribution from month to month throughout the year and its frequency are quite as important as the actual rainfall totals accumulated in a particular year, the conditions which cause cause precipitation in a region do not so exist in the same combination throughout the year. The variability of rainfall can, therefore, arguably though, be considered as an indicator of the changing state of the total atmospheric condition and consequently a major feedback parameter or index of climate variability and change, most especially from the hydrological point of view. This variability of rainfall over the Lower Niger River is considere for the six (6) gauging stations used in this study. The variability over a period from 1960 till 2007 is The variability over a period fill 1960 till 2007 linear relationship of these variabilities with time is given as:

$\boldsymbol{y}=-5.735 x+140.5$

(4)

where $y$ is the annual total rainfall deviation from the long term mean and $x$ is years.

Results revealed a significant trend in rainfall variabilities showing shreds of evidence of climate change as detected from the runs test analysis reported in Table 3. 


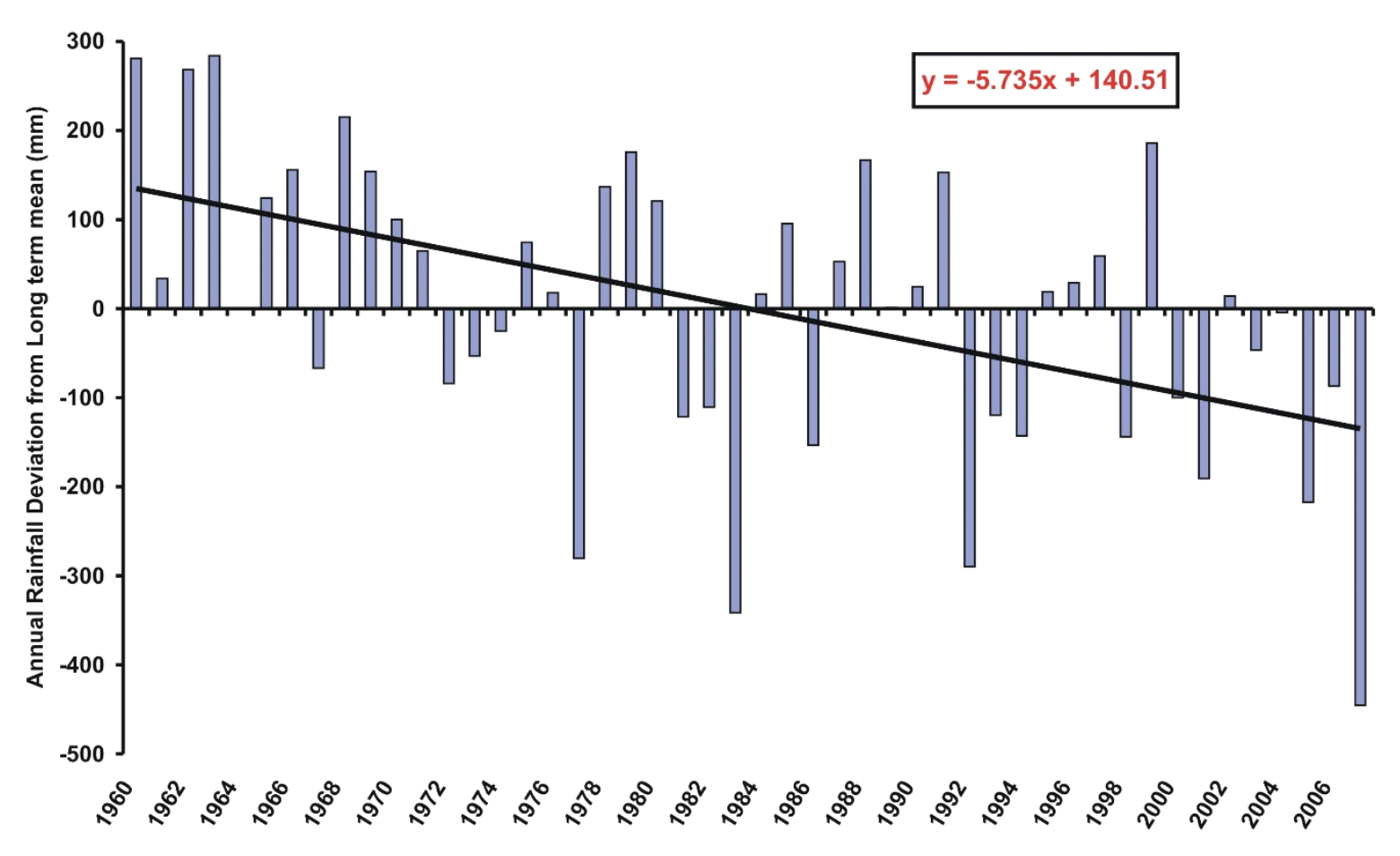

Fig. 2 Rainfall deviation from 1960-2007 mean

For each of the six gauging stations, Fig. 3 shows a graphical comparison between the observed annual rainfall variability and the GCM predictions from While the highest values almost annually at Jiddere Bode, CSIROMk 3 output reports about the highest values at Lokoja and Idah. Although CSIROMk3 and HadCM3 outputs reports the highest values at Baro, the case at Onitsha is not similar as HadCM3 reports the highest values, whereas, the observed rainfall amounts show the highest values at Aboh. The implication of these is that none of the GCMs adequately predicts the annual rainfall amounts. Results of the computed mean values of total precipitation amounts along with the corresponding standard deviations comparing the GCM predictions from CGCM3, CSIROMk3 and . rain gauge measurements further reveals the inadequacies of the GCMs in accurately predicting the variability in the annual rainfall. This is in consonance with previous studies which have shown the capacity of GCMs in predicting rainfal at higher resolution scales and the importance of downscaling techniques to provide improved forecasts and modelling (Xu et al., 2020; Narimis and Narimisa, 2018).

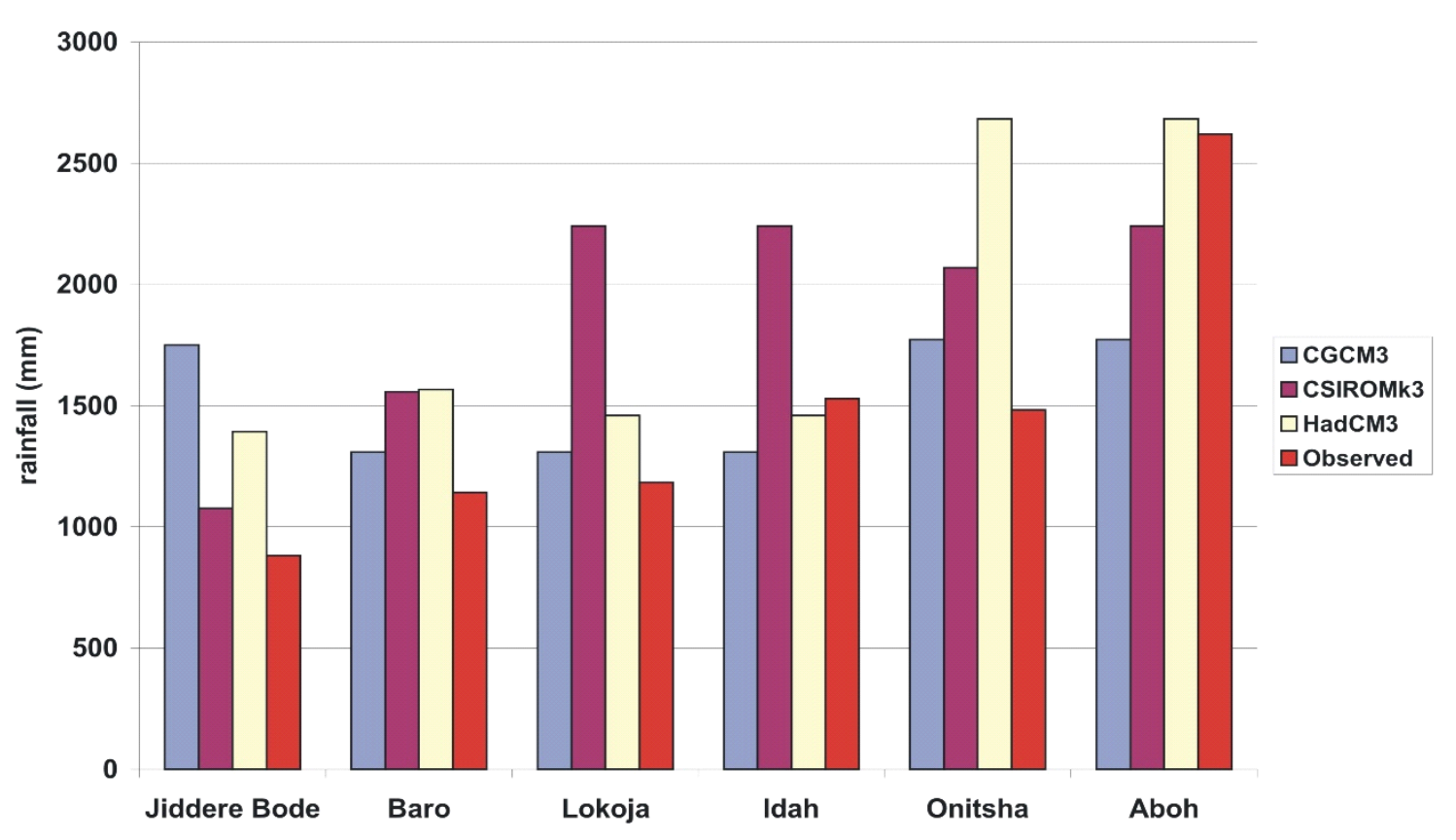

Fig. 3 GCM rainfall output compared with observed

\section{Table 3: Runs test of annual rainfall confirming climate change}

\begin{tabular}{|c|c|c|c|c|c|c|c|c|}
\hline \multicolumn{3}{|c|}{ Runs test statistics for annual rainfall } & $\begin{array}{l}\text { Jiddere } \\
\text { Bode }\end{array}$ & Baro & Lokoja & Idah & Onitsha & Aboh \\
\hline \multicolumn{3}{|c|}{ Test Value(a) } & 937.05 & 1150.86 & 1117.39 & 1510.56 & 1497.02 & 2378.52 \\
\hline \multicolumn{3}{|c|}{ Cases $<$ Test Value (Mean) } & 22 & 20 & 24 & 25 & 21 & 26 \\
\hline \multicolumn{3}{|c|}{ Cases? Test Value (Mean) } & 26 & 28 & 24 & 23 & 27 & 22 \\
\hline \multicolumn{3}{|c|}{ Total Cases } & 48 & 48 & 48 & 48 & 48 & 48 \\
\hline \multicolumn{3}{|c|}{ Number of Runs } & 3 & 3 & 2 & 4 & 5 & 3 \\
\hline \multicolumn{3}{|l|}{ Z } & -1.86 & 0.95 & -0.15 & -0.72 & -0.63 & -4.21 \\
\hline \multicolumn{3}{|c|}{ Asymptotic Significance (2-tailed) } & 0.06 & 0.03 & 0.08 & 0.04 & 0.05 & 0.00 \\
\hline \multirow{3}{*}{$\begin{array}{c}\text { Monte } \\
\text { Carlo Sig. } \\
\text { (2-tailed) }\end{array}$} & Significance & & 0.05 & 0.02 & 0.08 & 0.04 & 0.04 & 0.00 \\
\hline & $\begin{array}{l}95 \% \\
\text { Confidence }\end{array}$ & Lower Bound & 0.05 & 0.28 & 0.87 & 0.46 & 0.45 & 0.00 \\
\hline & Interval & Upper Bound & 0.06 & 0.30 & 0.89 & 0.49 & 0.47 & 0.00 \\
\hline
\end{tabular}

Furthermore, the result of the T-Test analysis of the thirty-year (1961-1990) period between the observation data and the GCM predictions from CGCM3, CSIROMk3 and HadCM3 presented in Table 4 however, presents HadCM3 predictions as the most reliable of the three GCMs in predicting the rainfall at the selected study sites. This is so because there is no significant statistical difference between the HadCM3 model and observed rainfall series at 5 of the 6 gauging stations (that is, Baro, Lokoja, Idah and Aboh). Further, that the positive correlation of $\mathrm{HadCM} 3$ predictions with that of the observed values is significant at $0.05 \alpha$-level in the three (3) gauging stations (that is, Lokoja, Idah and Onitsha) is a statistical basis to confirm the HadCM3 predictions as the best relating to the reality of the three GCMs.

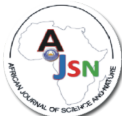

P-ISSN 2536-6904, E-ISSN 2705-2761 African Journal of Science \& Nature Vol. 10, $39-48$ (2020) 


\section{Table 4 T-test of annual observed rainfall and GCMs}

\begin{tabular}{|c|c|c|c|c|c|c|c|c|}
\hline & & \multicolumn{2}{|c|}{ Mean } & $95 \%$ Confidence Inte & erence & & \multicolumn{2}{|r|}{$\overline{\text { gnificance }}$} \\
\hline & $\overline{C \text { CGCM3 vs. Observed }}$ & Difference & $\frac{.6 \text { Error }}{32.01}$ & $\frac{\text { Lower }}{803.31}$ & $\frac{\text { Opper }}{934.28}$ & $\frac{t}{27.13}$ & $\frac{\mathrm{df}}{29}$ & $\frac{(2 \text {-tailed })}{0.06366}$ \\
\hline \multirow[t]{3}{*}{ Jiddere Bode } & CSIROMk3 vs. Observed & 194.68 & 48.52 & 95.43 & 293.92 & $4.01^{(a)}$ & 29 & \\
\hline & HadCM3 vs. Observed & 511.68 & 43.4 & 422.91 & 600.44 & 11.78 & 29 & 0.000139 \\
\hline & CGCM3 vs. Observed & 166.52 & 45.48 & 73.5 & 259.54 & 8.23 & 29 & 0.000994 \\
\hline \multirow{3}{*}{ Baro } & CSIROMk3 vs. Observed & 416.04 & 59.33 & 294.69 & 537.4 & 7.01 & 29 & 0.000104 \\
\hline & HadCM3 vs. Observed & 424.75 & 51.58 & 319.25 & 530.25 & $3.66^{(a)}$ & 29 & 0.070444 \\
\hline & CGCM3 vs. Observed & 123.99 & 36.52 & 49.29 & 198.69 & 3.39 & 29 & 0.002007 \\
\hline \multirow[t]{3}{*}{ Lokoja } & CSIROMk3 vs. Observed & 1056.11 & 58.63 & 936.18 & 1176.04 & 18.01 & 29 & 0.00275 \\
\hline & HadCM3 vs. Observed & 274.18 & 38.25 & 195.93 & 352.42 & $7.16^{(2)}$ & 29 & 0.0689 \\
\hline & CGCM3 vs. Observed & -220.49 & 68.2 & -359.98 & -80.99 & 3.23 & 29 & 0.003051 \\
\hline \multirow[t]{3}{*}{ Idah } & CSIROMk3 vs. Observed & 711.62 & 82.94 & 541.98 & 881.27 & 8.57 & 29 & 0.001909 \\
\hline & HadCM3 vs. Observed & -70.3 & 65.53 & 0 & 63.73 & $1.07^{(a)}$ & 29 & 0.092234 \\
\hline & CGCM3 vs. Observed & 289.53 & 54.84 & 177.36 & 401.7 & 5.27 & 29 & 0.001705 \\
\hline \multirow[t]{3}{*}{ Onitsha } & CSIROMk3 vs. Observed & 586.49 & 73.53 & 436.09 & 736.9 & $7.97^{(a)}$ & 29 & 0.080509 \\
\hline & HadCM3 vs. Observed & 1200.74 & 58.71 & 1080.65 & 1320.83 & $2.44^{(a)}$ & 29 & 0.08984 \\
\hline & CGCM3 vs. Observed & -848.38 & 73.04 & -997.78 & -698.98 & 11.61 & 29 & 0.000002 \\
\hline \multirow[t]{2}{*}{ Aboh } & CSIROMk3 vs. Observed & -379.83 & 86.27 & -556.28 & -203.38 & 4.4 & 29 & 0.000133 \\
\hline & HadCM3 vs. Observed & 62.82 & 70.79 & 0 & 207.61 & $0.88^{(a)}$ & 29 & 0.082189 \\
\hline
\end{tabular}

(a) Not significant at 0.05

Divergence, vorticity and wind direction on the surface of the earth as well as divergence at $850 \mathrm{hPa}$ and zonal velocity at $500 \mathrm{hPa}$ were found to be the major atmospheric predictors of rainfall. The downscaled rainfall had minimum bias from the observed series and predicted wet season rainfall amounts for all the stations. The case was however

\section{Table 5: Percent change in 2071-2099 runoff from 1961-1990 mean}

\begin{tabular}{ccrrr}
\hline & & $\begin{array}{c}\text { Upper } \\
\text { reaches }\end{array}$ & $\begin{array}{c}\text { Middle } \\
\text { reaches }\end{array}$ & $\begin{array}{c}\text { Lower } \\
\text { reaches }\end{array}$ \\
\hline \multirow{2}{*}{ Dry } & A1 & $1.75 \%$ & $39.49 \%$ & $39.16 \%$ \\
Season & A2 & $1.49 \%$ & $38.98 \%$ & $40.64 \%$ \\
& B1 & $1.67 \%$ & $39.43 \%$ & $39.84 \%$ \\
& & & & \\
Wet & A1 & $-41.25 \%$ & $22.78 \%$ & $53.24 \%$ \\
Season & A2 & $-41.25 \%$ & $22.75 \%$ & $53.22 \%$ \\
& B1 & $-41.27 \%$ & $22.72 \%$ & $53.29 \%$ \\
\hline
\end{tabular}

The modelled future (2071-2099) seasonal runoff variability for the three IPCC/SRES emission scenario A1, A2 and B1 are presented in Figures 4 for the upper, middle and lower reaches of the lower River Niger.

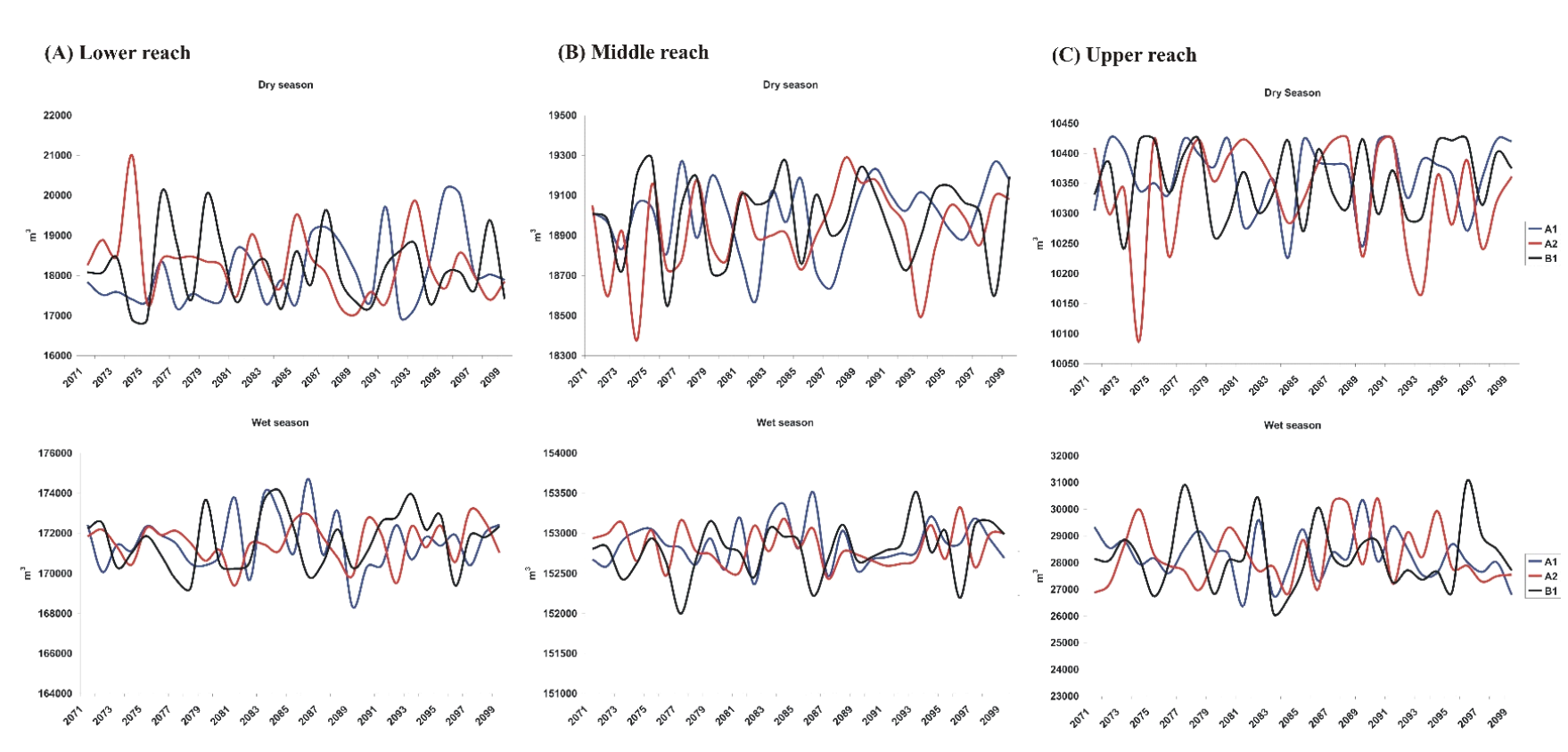

\section{Fig. 4 Future runoff predicted from scenario-based rainfall projection}

Future runoff predictions revealed a $2 \%$ to $40 \%$ (Table 2) increase in the dry season runoff from the 1961-1990 mean levels. However, a 45\% reduction is observed for wet season in the upper reaches with $17 \%$ to $60 \%$ increase in the middle to lower reaches.

\section{Conclusion}

HadCM3 predictions of precipitation when downscaled using a statistical technique based on stepwise regression and Bayesian forecasts implemented within the statistical downscaling model (SDSM) framework provides adequate explanations for the precipitation occurrences at the regional-to-local scale thus helping to generate a high-resolution prediction which is useful in assessing the impact of climate change on runoff and consequently on water resources in the future. Future runoff is therefore predictable from statistically downscaled HadCM3 rainfall outputs. While drought is expected in the savannah region While drought is expected in the savannah region
(upper reaches) of the lower River Niger due to (upper reaches) of the lower River Niger due to
increasing desiccation resulting from climate change, the rainforest region (lower reaches) would be prone to excessive flood risks due to increase in rainfall.

The thought of a drought in the north and flooding in the south in a single catchment is a most devastating state of any hydrological reasoning.

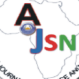

P-ISSN 2536-6904, E-ISSN 2705-2761 African Journal of Science \& Nature Vol. 10, $39-48$ (2020)
However this is the indication of the extreme nature of the future climate anticipated for the lower river Niger which is not only very importan for the socio-economic and political stability of Nigeria alone. The impact of this magnitude of climate change on the hydrological framework of the area would alter the hydrological cycle itself and invariably create a different water balance scheme which would affect human livelihood to a great extent. The implications thereof are numerous but the most important include desiccation in the upper reaches would increase the water stress, hence a strict defensive water resources strategy which would seek to continue to supply the water demand with a given level of reliability is recommended, such that it would also seek to meet those demand increases accompanying climate change as well as any increase occurring through the normal processes of economic growth.

Reduction in river flow magnitude in the upper reaches would affect irrigation and hydro-power generation, it is therefore recommended that a combination of defensive and adaptive strategy as suggested earlier should be adopted only that it would require a deviation from the business as usual manner where the government is not in total control of the use of water for commercial or agricultural purposes in form of direct irrigation (Akintola et al, 1979; Akintola and Areola, 1980). Alternative energy sources should be developed given the potentials for sustainable development 
and the enormous availability of resources such as solar radiation (Onafeso, 2005, 2006). In conclusion, high flows in the lower reaches would increase the risk of flooding, adequate plan to construct flood breaks and protect settlements closest to the river Niger is recommended.

\section{References}

Akintola, F.O. (1978). Urbanization in relation to human settlements and potential environmental problens Bulletin of the Science Association of Nigeria 3 (2):245-
252. 252.

Akintola, F.O., Areola, O.O. and Faniran, A. (1979). A survey of people's perception as a Method of establishing Standards for water Supply Schemes in Nigeria Water Supply and Management 3 (4):267-273.

Akintola, F.O. and Areola, O.O. (1980). Pattern and Strategy of Public Water Supply in Nigeria Nigerian Journal of Economic and Social Studies 22(1):44 - 52.

Beldring, S., Andreasson, J., Bergström, S., Graham, L. P., Jonsdottir, J. F., Roald, L. A., Rogozova, S., Rosberg, J., Suomalainen, M., Vehviläinen, B., Veijalainen, N. (2007). Climate change impacts on hydrological processes in the Nordic region 2071-2100. In 16th International Northern Research Basins Symposium and Workshop Petrozavodsk, Russia, 27 Aug. - 2 Sept. 2007

Bormann, H. Giertz, S, and Diekkruger, B. (2005). Hydrological catchment models: process representation, data availability and applicability for water management case study for Benin. In Regional Hydrological Impacts of Climate Variability and Change-Impact Assessment and Decision Making Proceedings of symposium S6 held during the Seventh IAHS Scientific Assembly at Foz do Iguacu, Brazil, April 2005. IAHS Publ. 295, 2005. pp. 86-93.

Christensen, J.H., B. Hewitson, A. Busuioc, A. Chen, X. Gao, I. Held, R. Jones, R.K. Kolli, W.-T. Kwon, R. Laprise, V. Magaña Rueda, L. Mearns, C.G. Menéndez, J. Räisänen, A. Rinke, A. Sarr and P. Whetton, (2007). Regional Climate Projections. In: Climate Change 2007:
The Physical Science Basis. Contribution of Working Group I to the Fourth Assessment Report of the Intergovernmental Panel on Climate Change [Solomon, S., D. Qin, M. Manning, Z. Chen, M. Marquis, K.B. Averyt, M. Tignor and H.L. Miller (eds.)] Cambridge University Press, Cambridge, United Kingdom and New York, NY, USA.

Leung, L.R. and Qian, Y. (2005). Hydrological response to climate variability, climate change, and climate extreme in the USA: change, and climate extreme in the USA:
climate model evaluation and projections. climate model evaluation and projections. In Regional Hydrological Impacts of Assessment and Decision Making. Proceedings of symposium S6 held during the Seventh IAHS Scientific Assembly at Foz do Iguacu, Brazil, April 2005. IAHS Publ. 295:37-44.

McGuffie, K. and Henderson-Sellers, A. (2001) Forty years of numerical climate J Climatol. 21: 1067109

Narimisa, M. R. and Narimisa, M. R. (2018) Assessing Climate Change and Globa Warming in local scale. Revista Publicando 5 (2): 570-580

Okpara, J. N. and Perumal, M. (2009) Hydrological impact assessment of climate change on water resources of the Niger River basin using a water bal the cher model and ANN. In (Ed. Cluckie et al, Hydroinformatics in Hydrology, Hydrogeology and Water Resources. Proceedings of Symposium JS.4 at the Joint IAHS \& IAH Convention, Hyderabad, India. IAHS Publ. 331: 58-71.

Onafeso O. D. (2005). Seasonal and Spatia Distribution of Direct Solar Radiation over Nigeria from Geostationary Satellite. An unpublished MSc. Thesis submitted Geography to the Department of Geography, University of lbadan

Onafeso O. D. (2006). The Need for Governmen Ownership of Solar Energy Production in the Achievement of the Millennium Development Goals in Nigeria. Nigeria Journal of Solar Energy 16:143-154

Hreiche, A., Bocquillon, C., Najem, W., and
Dandach, D (2005). The potential impact of future climate change on Lebanese river basin hydrology using scenarios. In Regional Hydrological Impacts of Climate Variability and Change - Impact Assessment and Decision Making Proceedings of symposium S6 held during the Seventh IAHS Scientific Assembly at Foz do Iguacu, Brazil, April 2005. IAHS Publ. 295, 2005.pp. 103-110.

Kunstmann, H., and Jung, G. (2005). Impact of regional climate change on water availability in the Volta basin of West
Africa. In Regional Hydrological Impact of Climate Variability and Change Impact Assessment and Decision Making Proceedings of symposium S6 held during the Seventh IAHS Scientific Assembly at Foz do Iguacu, Brazil, April 2005. IAHS Publ. 295:75-85.

Xu, R., Chen, N., Chen, Y. and Chen, Z. (2020) Downscaling and Projection of MultiCMIP5 Precipitation Using Machine CMres Precipition Using Machire Learning Methods in the Upper Han River Basin. Advances in Meteorology
https://doi.org/10.1155/2020/8680436 